\title{
Lignin Derivatives Formation In Catalysed Thermal Decomposition Of Elephant Grass Lignocellulose
}

\author{
K.I. Ekpenyong,* E. A. Clement, O.S. Olatunde and N.Obi \\ Department of Chemistry, University of Jos, PMB 2084 Jos, Nigeria
}

\begin{abstract}
Decomposition of elephant grass (Panicum maxima) lignocellulose was carried out with Pd and Ni/Pt-doped alumina as catalysts; chromic oxide was also used in some cases. For systems that contained no chromic oxide, formation of gaseous and volatile liquid products was highest for $\mathrm{Ni} / \mathrm{Pt}$, intermediate for $P d / \lambda$ - and least for Pd/ $\gamma$-alumina. Non-volatile (tar) liquid product formation, on the other hand, was highest for $P d / \lambda$-, intermediate for Pd/ $\gamma$ - and least for Ni/Pt-alumina. In these systems, product formation in detectable and measurable amounts was first observed at $140^{\circ} \mathrm{C}$. For systems that contained chromic oxide, product formation was first observed at $60^{\circ} \mathrm{C}$. The order of reactivity of the catalysts was $\mathrm{Ni} / \mathrm{Pt}->$ $P d / \lambda->P d / \gamma$ alumina for the gaseous and $P d / \gamma->P d / \lambda->N i / P t$-alumina for the volatile liquid products in the range of $100-140^{\circ} \mathrm{C}$. For the nonvolatile (tar) liquid products, the order was $P d / \gamma_{-}>P d / \lambda->N i / P t$-alumina in the range of $60-80{ }^{\circ} \mathrm{C}$ and $\mathrm{Pd} / \gamma->\mathrm{Ni} / \mathrm{Pt}->\mathrm{Pd} / \lambda$ - alumina at $100-$ $120^{\circ} \mathrm{C}$. Generally, gaseous and volatile liquid products increased with increase in temperature. Also, all the three product types were formed in significantly higher concentrations in systems without chromic oxide than those with it. Mass spectral analysis of the tar product of two Ni/Ptalumina samples run at $180^{\circ} \mathrm{C}$ and $200^{\circ} \mathrm{C}$ without chromic oxide gave several products amongwhich 4-hydroxy-3-methoxybenzaldehyde, 4hydroxy-3, 5-dimethylbenzaldehyde, 3-isobutyl-4-hydroxy-5methoxybenzaldehyde, 3-methoxycinnamic acid, and ethanone1(4hydroxy-3-methoxyphenyl) were identified. $\quad$ *Author for correspondence
\end{abstract}

INTR

\section{ODUCTION}

Biomass in the form of household, municipal, industrial and agricultural wastes will continue to play an important role in the generation of energy, fuels and chemicals. Biomass is relatively abundant and renewable, and this makes it particularly attractive in relation to the non-renewable fossil fuels.

For the past several years, we have been engaged in the biochemical and thermochemical conversion of grasses and straws, in particular sorghum straws and the elephant grass $^{1-3}$. A vast expanse of grassland extends far and wide, north and south of the equator in the savannah region of the African continent. Some of this is used as pasture, the dry material as fuel and roofing material in home construction, but the bulk of the dry material is flared away, usually in preparation of the land for the next planting season. These grasses and straws constitute an enormous energy resource. From all indications ${ }^{4}$, it is apparent that a combination of biochemical and thermochemical methods would 
definitely be needed to maximally tap the energy potentials of these grasses and straws. Thermochemical methods such as pyrolysis and gasification can be regulated to generate liquid fuels, particularly by the process of catalysis with controlled temperature conditions.

The composition of grasses and straws is largely lignocellulosic ${ }^{5,6}$. For the stems of monocotyledons, grasses, bamboos, wheat, rice and sugar cane, Katzen $^{5}$ reports the following compositional ranges: cellulose $(25-40 \%)$; hemicellulose (25-50\%); lignin (10-30\%). In the case of wheat straw, Scott and coworkers ${ }^{6}$ report the following: cellulose (32.4\%); hemicellulose (41.8\%) and lignin (16.7\%). These values are well within the Katzen ranges. The cellulose and lignin compositions of the elephant grass, the focus of the present study, can be expected to lie within the given ranges.

Pyrolysis of agricultural wastes has been reported abundantly in the literature. ${ }^{7-}$ 11 .

Kaminsky $^{12}$ has discussed in great detail the existing pyrolytic methods including detailed product compositions of pyrolysed biomass materials.

Thermocatalytic

biomass decomposition has also been reported ${ }^{13-15}$. $\mathrm{Chen}^{13}$, for example, observed a decrease in the heat of gasification and mass fraction of non-combustible volatiles in solid $\mathrm{NaOH}$-catalysed thermal decomposition of pure and fire-retardantcellulose. Kuroda and co-workers ${ }^{14}$ studied the Curie-point pyrolysis of Japanese softwood species of the red pine, cedar and cypress in the presence of inorganic substances. The studies were carried out in the temperature range of $358-764^{\circ} \mathrm{C}$ with the goal of obtaining larger yields of lignin-derived products. The $\mathrm{Al}-\mathrm{Cu}-\mathrm{Cr}$ oxide system has been used as a catalyst in fluidized bed thermal decomposition of wood lignin; high quality carbon was produced while harmful pyrolysis products were eliminated ${ }^{15}$. These examples illustrate the potentials of catalyzed pyrolytic biomass decomposition. Evidently ${ }^{13}$, biomass thermocatalysis does not only cause the lowering of the reaction temperature but can also be employed to selectively obtain desired products among gases, volatile and non-volatile liquids. Pyrolysis of the various plant materials has been shown to give high yields of liquid products ${ }^{16}$. Pyrolysis tars, which contain oxygenated liquids in addition to regular hydrocarbons, can become important gasoline blends in the current efforts to reduce pollution resulting from sulphur oxide emissions of fossil fuels.

Because of the importance currently being attached to pyrolytic tar products, we undertook in the present study to also determine the kinds of chemical compounds contained in such products.

\section{EXPERIMENTAL}

\section{Samples}

Elephant grass samples used for the present study were obtained from the University of Jos surroundings. These comprised the plant stalk, cut above the roots. These were chopped into small pieces, washed, oven-dried at $100^{\circ} \mathrm{C}$ for two hours, cooled and ground to $<250 \mu \mathrm{m}$ mesh size.

\section{Sample extraction}

Each sample so treated was next extracted by the method of Crawford ${ }^{17}$ in order to remove the protein and carbohydrate components. The sequential extraction was first with water, next with 
benzene-ethanol mixture $(1: 1, \mathrm{v} / \mathrm{v})$, followed finally by each of ethanol and water, respectively. Each extraction was for 30 minutes at $80^{\circ} \mathrm{C}$. The soxhlet extractor was used. The resultant residue was oven-dried for 48 hours at $105^{\circ} \mathrm{C}$. The final product was stored in a desiccator until needed for further use.

\section{Catalysts}

The catalysts had the following compositions: $0.5 \%$ for $\mathrm{Pd}$ and $1.0 \%$ for each of $\mathrm{Ni}$ and Pt. Alumina of the $\lambda$ and $\gamma$ types were used. Their $\mathrm{Pd}$ and $\mathrm{Ni} / \mathrm{Pt}$ dopes as $\mathrm{Pd} / \lambda-, \mathrm{Pd} / \gamma_{-}$and $\mathrm{Ni} / \mathrm{Pt}$ - were used directly as obtained from the manufacturers.

\section{The reactor and heating system}

The reactor consisted of pyrex tubes of $16 \mathrm{~cm}$ length and $1.5 \mathrm{~cm}$ internal diameter. The heating medium was a cylindrical brass block of $9 \mathrm{~cm}$ height and $7 \mathrm{~cm}$ diameter into which three thermal wells were drilled at approximately equal distance apart. Each well had a depth of $7 \mathrm{~cm}$ and $1.7 \mathrm{~cm}$ diameter,

\section{The pyrolysis sample}

For a typical run, each tube was charged with the predetermined amount of lignocellulose (LC) or the $\mathrm{LC} /$ catalyst $/ \mathrm{Cr}_{2} \mathrm{O}_{3}$ blend. Each charge contained 1-2g LC and 40mg catalyst. For systems that contained chromic oxide, a blend of $\mathrm{LC} / \mathrm{Cr}_{2} \mathrm{O}_{3}(1: 2$, w/w) was used. After each loading, the open end of the tube was narrowed by drawing a capillary. A small piece of cotton wool was next inserted at the capillary end and the tube evacuated to a pressure of about $1 \mathrm{~mm} \mathrm{Hg}$. On removal of the cotton wool, the tube was sealed by means of a butane/oxygen flame.

\section{The pyrolysis and product recovery}

The samples, now contained in the sealed and evacuated tubes, were next inserted into the preheated thermal wells. Each sample was pyrolysed for $2 \mathrm{~h}$; the pyrolysis temperature varied between $60^{\circ}$ and $200^{\circ} \mathrm{C}$. At the end of each run the tubes were cooled and then cracked open, thereby allowing the gaseous products to escape.

\section{The gaseous products}

The difference in weight of the evacuated and sealed tube prior to pyrolysis and the cracked open tube (glass pieces included) gave the collective weight of the gaseous products.

\section{Non-volatile and volatile liquid fractions}

The residual reactor material was soxhlet -extracted in benzene for $72 \mathrm{~h}$. This gave the weight of the non-volatile (tar) liquid (NVL) product. By mass balance of gaseous, non-volatile liquid, residual material after soxhlet extraction, the weight of the volatile liquid (VL) fraction could be determined.

\section{Analysis of NVL fractions for components}

In addition, the benzene-extracted $\mathrm{NVL}$ fractions of $\mathrm{LC} / \mathrm{Ni} / \mathrm{Pt}-\mathrm{Al}_{2} \mathrm{O}_{3}$, run at $180^{\circ} \mathrm{C}$ and $200^{\circ} \mathrm{C}$, without chromic oxide, were analyzed by GC/MS for their chemical constituents. These low retention mass spectra were recorded on the Hewlett-Packard 5890 GC, equipped with a flame ionization detector and the Hewlett-Packard 5972 mass selective detector. The compounds were identified with the help of the Wiley 138.L Database 


\section{RESULTS AND DISCUSSION}

Tables 1 and 2 show, respectively, the results of the computational analysis for the products (gases, volatile and nonvolatile liquids) of systems that contained chromic oxide and those that did not. In Figures 1-5, the mass spectra of the tar products, identified as 4-hydroxy-3methoxybenzaldehyde, 4-hydroxy-3, 5dimethylbenzaldehyde, 3methoxycinnamic acid, ethanone-1 (4hydroxy-3-methoxyphenyl) and 3-isobutyl4-hydroxy-5-methoxybenzaldehyde are presented.

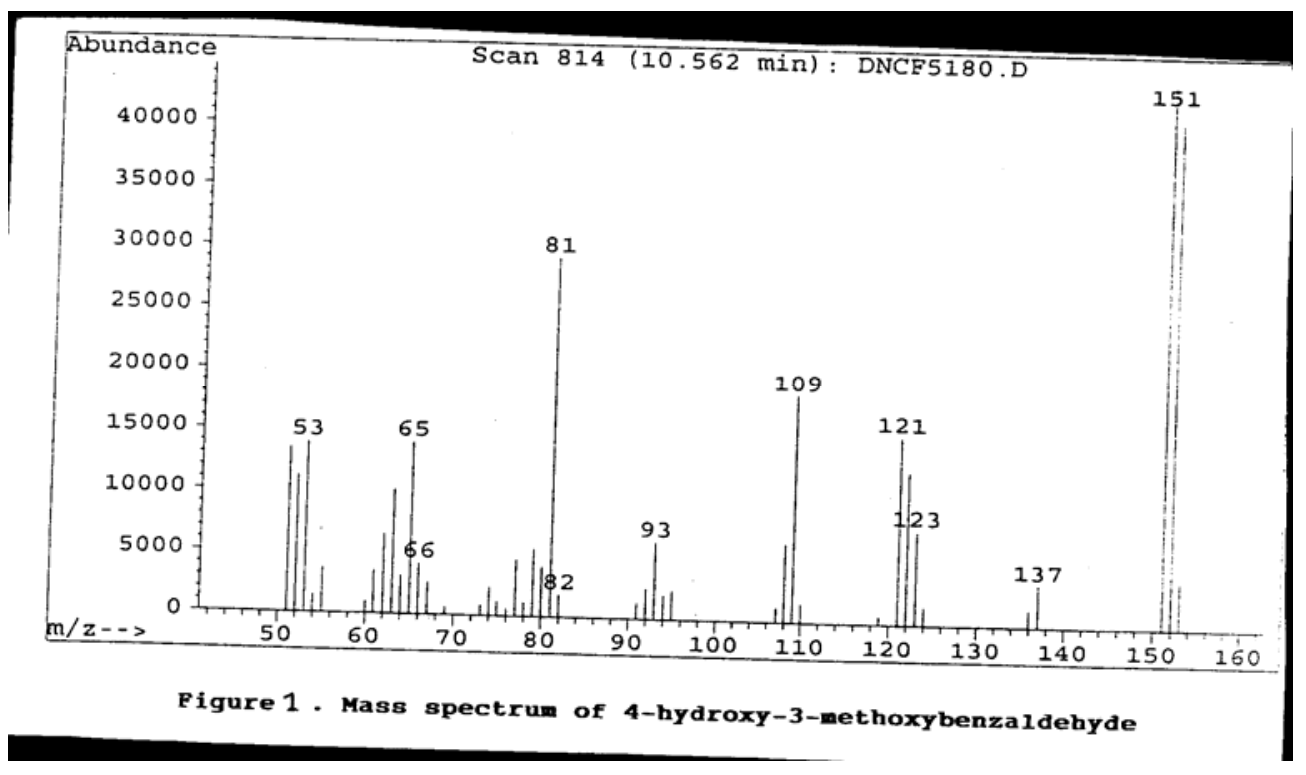

\section{Systems without $\mathrm{Cr}_{2} \mathrm{O}_{3}$}

Preliminary studies with lignocellulose (LC) alone showed that products formation in measurable quantities did not occur below $180^{\circ} \mathrm{C}$. The first determinable product mixture was obtained for runs carried out at $180^{\circ} \mathrm{C}$ and in the $180^{\circ} \mathrm{C}$ to $200^{\circ} \mathrm{C}$ range the amount of product formed was relatively small.
When the various catalysts were added to $\mathrm{LC}$, products were formed in measurable quantities at a temperature as low as $140^{\circ} \mathrm{C}$. The gaseous and volatile liquid products increased quantitatively with increase in temperature; the non-volatile liquids, on the other hand, decreased with increase in temperature (Table 1) 


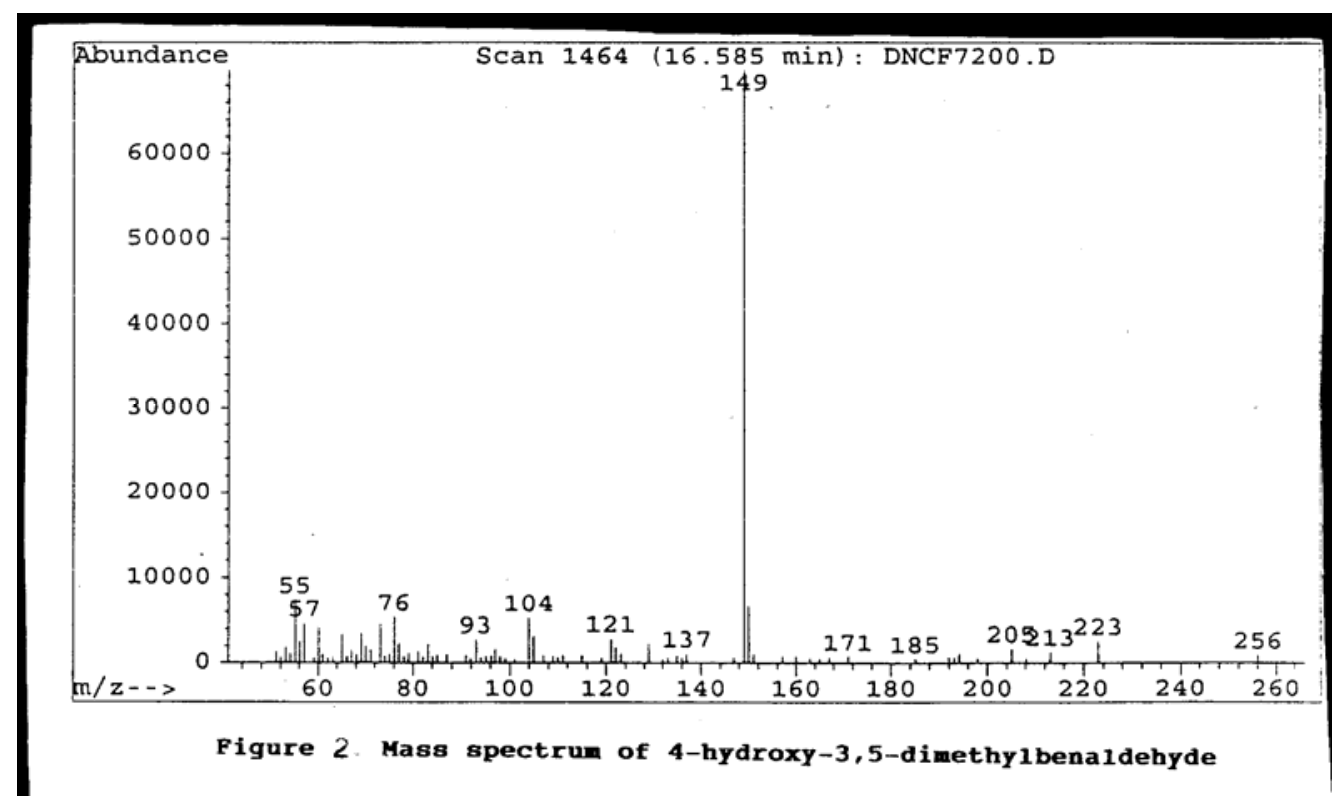

\section{Systems with $\mathrm{Cr}_{2} \mathrm{O}_{3}$}

With $\mathrm{LC} / \mathrm{Cr}_{2} \mathrm{O}_{3}$ without the catalysts, products were first obtained at $80^{\circ} \mathrm{C}$. When the various catalysts were added, product measurement was possible starting at as low as $60^{\circ} \mathrm{C}$. Noteworthy in these systems also is that while the concentrations of gaseous and, to some extent, volatile liquid products were significantly higher, those of the nonvolatile liquid products were considerably lower than those of systems without $\mathrm{Cr}_{2} \mathrm{O}_{3}$ (compare Tables 1 and 2 at $140^{\circ} \mathrm{C}$ ).

The results of Tables 1 and 2 provide the following classification of the activity of the catalysts: $\mathrm{Ni} / \mathrm{Pt}->\mathrm{Pd} / \lambda->$ $\mathrm{Pd} / \gamma-\mathrm{Al}_{2} \mathrm{O}_{3}$ in the formation of gaseous and volatile liquid products in the systems without chromic oxide. Similarly, for the NVL the order was $\mathrm{Pd} / \lambda>\mathrm{Pd} / \gamma->\mathrm{Ni} /$ Pt- $\mathrm{Al}_{2} \mathrm{O}_{3}$. For systems containing chromic oxide, the catalyst order of activity was found to be $\mathrm{Ni} / \mathrm{Pt}->\mathrm{Pd} / \lambda->\mathrm{Pd} / \gamma-$ alumina for the gaseous products; $\mathrm{Pd} / \gamma->$ $\mathrm{Pd} / \lambda->\mathrm{Ni} / \mathrm{Pt}-$ for the volatile liquids in the range of $100^{\circ}-140{ }^{\circ} \mathrm{C}$. For the NVL the order was $\mathrm{Pd} / \gamma->\mathrm{Pd} / \lambda->\mathrm{Ni} / \mathrm{Pt}-$ in the range of $60-80^{\circ} \mathrm{C}$ and $\mathrm{Pd} / \gamma->\mathrm{Ni} /$ $\mathrm{Pt}->\mathrm{Pd} / \lambda$ - alumina at $100-120^{\circ} \mathrm{C}$.

Generally, volatile and gaseous products increased in quantity with increase in temperature; non-volatile liquids, on the other hand, decreased with increase in temperature. The preponderance of the gaseous and VL products at the higher temperatures and the corresponding decrease in the NVL makes the following reaction scheme plausible.

$$
\mathrm{NVL} \leftrightarrow \mathrm{VL} \leftrightarrow \text { Gas. } / \text { blend } \rightarrow
$$

The transitions associated with this reaction scheme are temperature dependent. The results of Tables 1 and 2 show $\mathrm{Ni} / \mathrm{Pt}-\mathrm{Al}_{2} \mathrm{O}_{3}$, a multi- functional catalyst, to be a good candidate for the formation of gaseous products in lignocellulose decomposition. $\mathrm{Pd} / \lambda$ - and $\mathrm{Pd} / \gamma-\mathrm{Al}_{2} \mathrm{O}_{3}$, on the other hand, are well suited to the production of VL and NVL. $\mathrm{Bi}$-functional and multi-functional 
Table 1: Product Yields (\%) of Systems Without $\mathrm{Cr}_{2} \mathrm{O}_{3}$

\begin{tabular}{|c|c|c|c|c|c|c|c|c|c|c|c|c|}
\hline \multicolumn{4}{|c|}{ Gases } & \multicolumn{3}{c|}{ Volatile Liquids (VL) } & \multicolumn{3}{c|}{ Non-Volatile Liquids (NVL) } \\
\hline $\begin{array}{c}\text { Sampl } \\
\mathrm{e}\end{array}$ & $140^{\circ} \mathrm{C}$ & $160^{\circ} \mathrm{C}$ & $180^{\circ} \mathrm{C}$ & $200^{\circ} \mathrm{C}$ & $140^{\circ} \mathrm{C}$ & $160^{\circ} \mathrm{C}$ & $180^{\circ} \mathrm{C}$ & $200^{\circ} \mathrm{C}$ & $140^{\circ} \mathrm{C}$ & $160^{\circ} \mathrm{C}$ & $180^{\circ} \mathrm{C}$ & $200^{\circ} \mathrm{C}$ \\
\hline 0 & - & - & 3.0 & 3.5 & - & - & 7.3 & 8.3 & - & - & 2.5 & 3.5 \\
\hline 1 & 10.9 & 17.1 & 21.0 & 26.0 & 8.2 & 9.6 & 13.4 & 18.2 & 19.5 & 16.4 & 12.7 & 7.3 \\
\hline 2 & 12.7 & 19.5 & 24.3 & 33.2 & 7.7 & 11.3 & 15.5 & 23.2 & 21.3 & 18.7 & 15.3 & 12.5 \\
\hline 3 & 17.1 & 27.4 & 31.0 & 36.9 & 14.8 & 19.5 & 24.0 & 24.0 & 18.5 & 15.8 & 11.7 & 8.1 \\
\hline
\end{tabular}

$\mathrm{O}=\mathrm{LC}$ only; $1 . \mathrm{LC}+\mathrm{Pd} / \gamma-\mathrm{Al}_{2} \mathrm{O}_{3} ; 2 . \mathrm{LC}-\mathrm{pd} \lambda-\mathrm{Al} 2 \mathrm{O} 3 ; 3 . \mathrm{LC}+\mathrm{Al}_{2} \mathrm{O}_{3}$

Table 2: Product Yields (\%) of Systems Containing $\mathrm{Cr}_{2} \mathrm{O}_{3}$

\begin{tabular}{|c|c|c|c|c|c|c|c|c|c|c|c|c|c|c|c|}
\hline \multicolumn{5}{|c|}{ Gases } & \multicolumn{5}{|c|}{ Volatile Liquids (VL) } & \multicolumn{6}{|c|}{ Non-Volatile Liquids (NVL) } \\
\hline Sample & $60^{\circ} \mathrm{C}$ & $80^{\circ} \mathrm{C}$ & $100^{\circ} \mathrm{C}$ & $120^{\circ} \mathrm{C}$ & $140^{\circ} \mathrm{C}$ & $60^{\circ} \mathrm{C}$ & $80^{\circ} \mathrm{C}$ & $100^{\circ} \mathrm{C}$ & $120^{\circ} \mathrm{C}$ & $140^{\circ} \mathrm{C}$ & $60^{\circ} \mathrm{C}$ & $80^{\circ} \mathrm{C}$ & $100^{\circ} \mathrm{C}$ & $120^{\circ} \mathrm{C}$ & $140^{\circ} \mathrm{C}$ \\
\hline 0 & - & 1.0 & 1.4 & 1.6 & 1.8 & - & 3.0 & 3.8 & 4.5 & 4.7 & - & 0.4 & 0.3 & 0.3 & 0.3 \\
\hline 1 & 4.2 & 5.6 & 6.8 & 9.1 & 11.9 & 4.5 & 5.5 & 7.1 & 9.5 & 10.3 & 17.8 & 15.2 & 10.3 & 8.8 & 6.1 \\
\hline 2 & 9.1 & 10.6 & 12.8 & 15.2 & 17.8 & 1.6 & 3.7 & 6.4 & 8.8 & 11.8 & 14.2 & 12.3 & 8.8 & 6.7 & 4.8 \\
\hline 3 & 10.2 & 12.1 & 14.2 & 16.7 & 19.4 & 3.1 & 4.0 & 4.9 & 8.5 & 8.6 & 11.6 & 11.0 & 9.9 & 8.7 & 4.4 \\
\hline
\end{tabular}

$\mathrm{O}=\mathrm{LC}$ only; 1. $\mathrm{LC}+\mathrm{Pd} / \gamma-\mathrm{Al}_{2} \mathrm{O}_{3} ; 2 . \mathrm{LC}-\mathrm{pd} \lambda-\mathrm{Al} 2 \mathrm{O} 3 ; 3 . \mathrm{LC}+\mathrm{Al}_{2} \mathrm{O}_{3}$

catalysts have been studied quite extensively $^{18}$

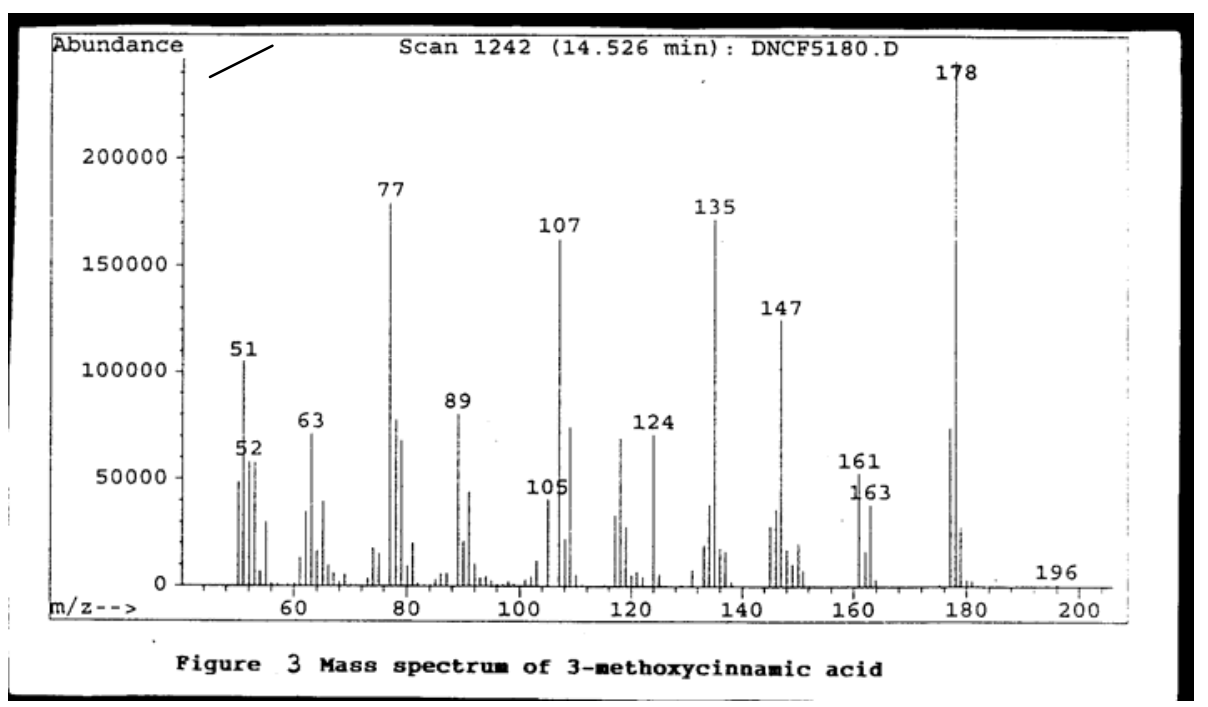

Nigerian journal of chemical research, 
and are already being employed widely in industry. The results of our present studies can be quite important in the present strong interest for liquid fuels from biomass.

A meaningful interpretation of the mass spectra (Figures $1-5$ ) requires reference to the structure of lignin, and specifically lignocellulose. Such structures have been proposed. ${ }^{19,20}$ Figure 1 shows the mass spectrum of the compound identified as 4- hydroxy-3methoxybenzaldehyde, of molecular weight 152 . It has an $(\mathrm{M}+1)$ peak of low intensity (m/e 153) and an (M-1) peak, which is the base peak $(\mathrm{m} / \mathrm{e} 151)$. Some of its most significant ion fragment peaks are accounted for in the scheme presented. Mass fragment peaks at m/e 122 and 121 are formed by the successive loss of an $\mathrm{H}$ atom from the m/e 123 ion fragment. Similarly, the peaks at $\mathrm{m} / \mathrm{e} 81,77$ and 65 are formed from the m/e 93 fragment as follows:

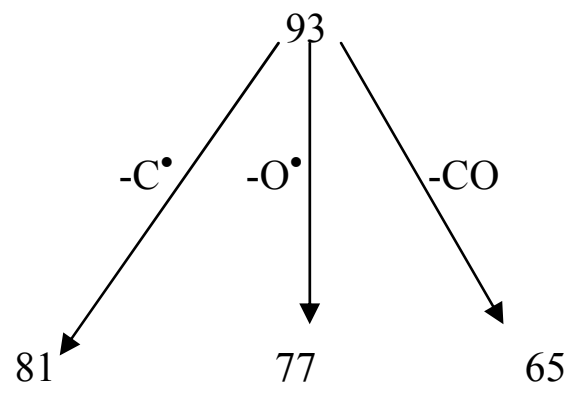

Peaks below m/e 65 are due to either lower cyclic or open chain structures. A fragment peak at $\mathrm{m} / \mathrm{e} 55$ (not labeled) is commonly associated with the methylallylation which is quite stable. The $\mathrm{m} / \mathrm{e} 53$ could easily be formed from this fragment by loss of two hydrogen atoms.<smiles>C=CC(C)C1CCC1C</smiles><smiles>COc1cc(C=O)ccc1C</smiles> 


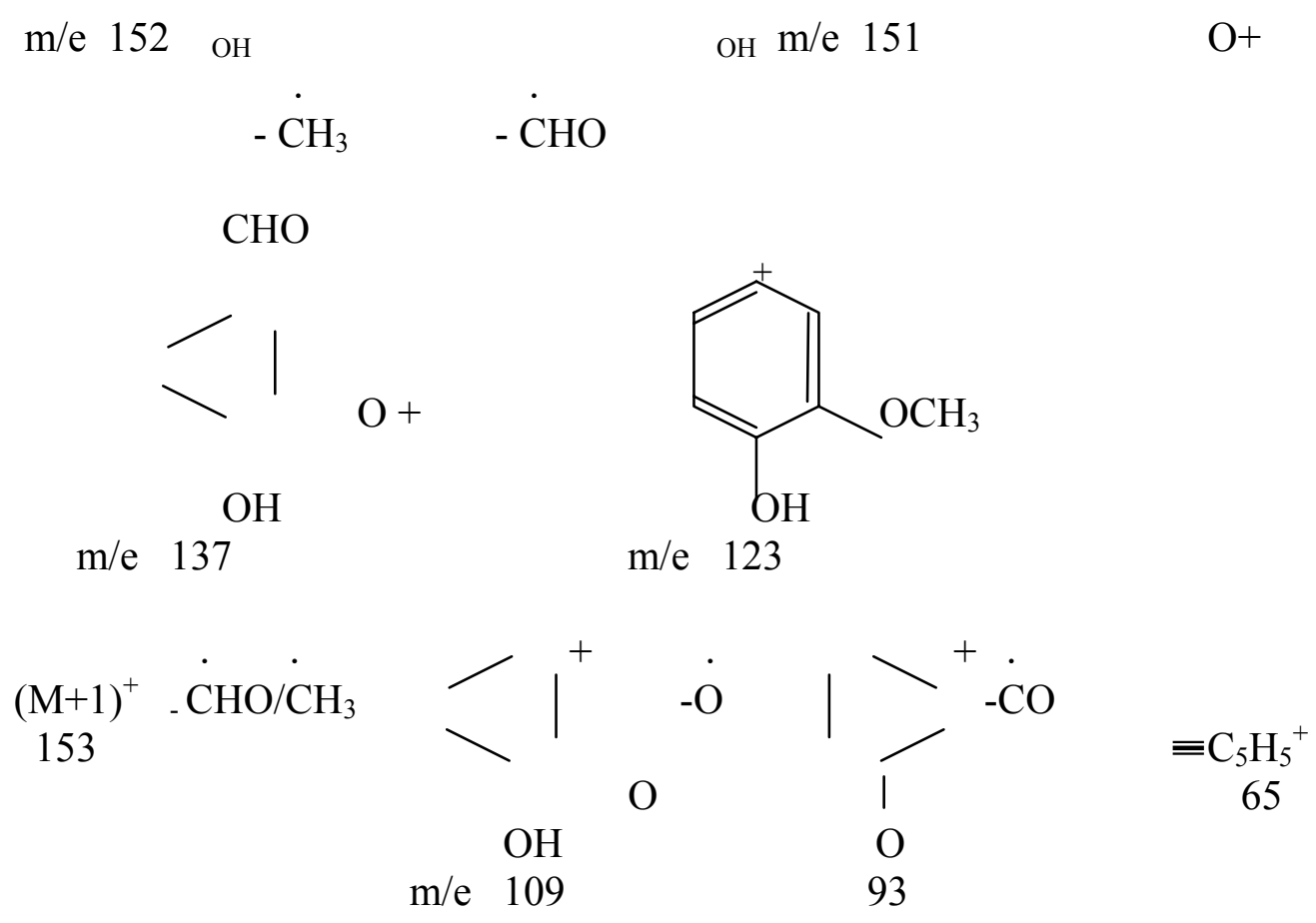

Scheme for the fragmentation of 4- hydroxy -3 - methoxybenzaldehyde

Figure 2 represents the mass spectrum of 4-hydroxy - 3,5- dimethylbenzaldehyde of molecular weight 150 . The compound is the stable molecule that results after loss of some substituents from the benzene ring. This seems to be the case because of the series of peaks of relatively low intensity above $\mathrm{m} / \mathrm{e}$ 150, e.g. $171,185,205,213$, 223 , 256. The (M-1) peak at $\mathrm{m} / \mathrm{e} 149$ is the base peak and is formed from the molecular ion fragment by loss of an $\mathrm{H}$ atom. 


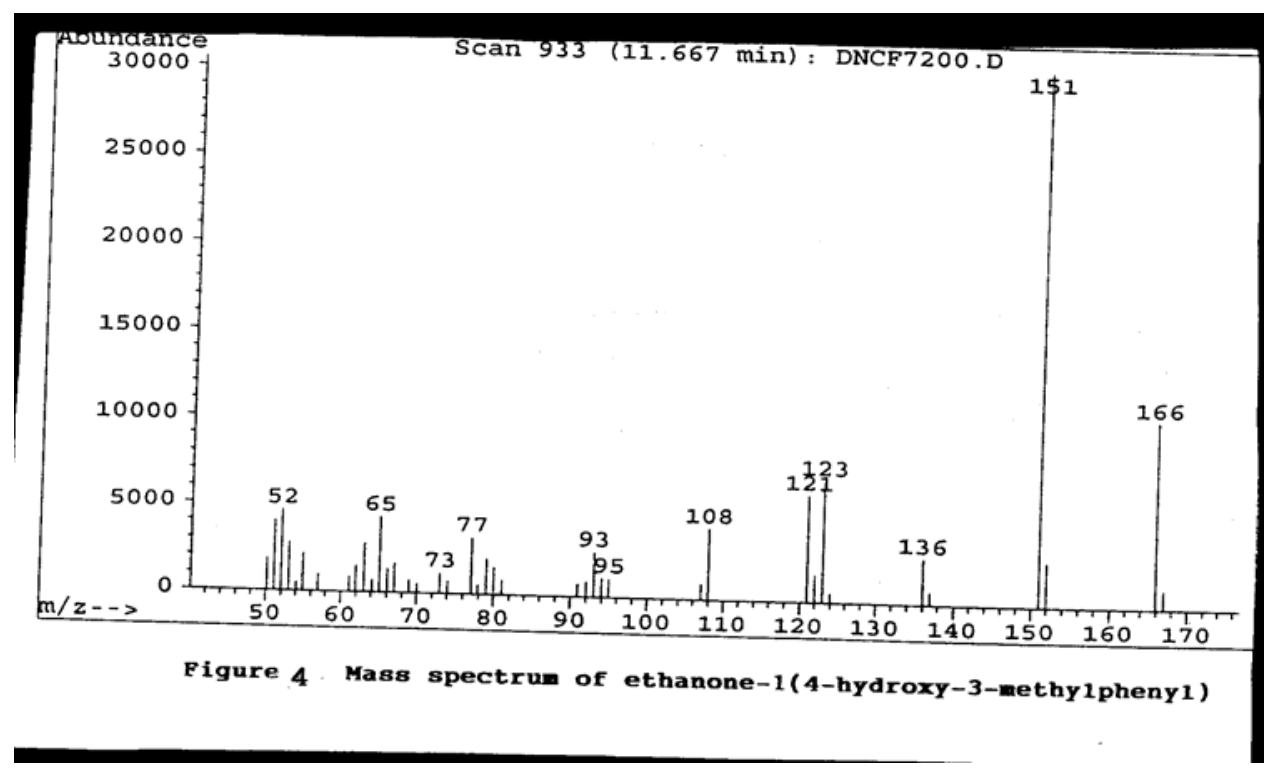

The mass spectrum of Figure 3 is that of 3methoxycinnamic acid of molecular weight 178. It has an $(\mathrm{M}+1)$ peak at $\mathrm{m} / \mathrm{e} 179$ and an (M-1) at $\mathrm{m} / \mathrm{e} 177$, both having intensities characteristic of an aromatic ether. $^{21}$

Figure 4 represents the mass spectrum of ethanone-1 (4-hydroxy-3methoxyphenyl) of molecular weight 166. It has an $(\mathrm{M}+1)$ peak at $\mathrm{m} / \mathrm{e} 167$.

Figure 5 shows characteristically, a substituted benzene ring, which has been identified as 3-isobutyl-4- hydroxy-5methoxybenzaldehyde, of molecular formula $\mathrm{C}_{12} \mathrm{H}_{16} \mathrm{O}_{3}$ and weight of 208 .

Formation of the various fragment peaks of Figures $2-5$ can be established in the manner already discussed for Figure 1.

Noteworthy in all five compounds is the similarity in the locations of peaks characteristic of certain fragment ions that are common to them. This is particularly true of the three compounds with the benzaldehyde unit. Furthermore, the lignin polymer contains polyphenylpropanoid units. Much of the phenyl propane monomer structure of lignin is therefore retained in these reactions as evident from the structures of the compounds reported here and such observations have been made previously. ${ }^{22}$ The performance of the three alumina-supported metal catalysts with and without $\mathrm{Cr}_{2} \mathrm{O}_{3}$ is novel in this study. Lignocellulose decomposition and product formation in sizeable quantities occur at remarkably low temperatures. While the presence of $\mathrm{Cr}_{2} \mathrm{O}_{3}$ has the effect of temperature lowering and higher yields of the gaseous and, to some extent, liquid products, it leads also to a drastic reduction in the amounts of the non-volatile liquid products formed. 


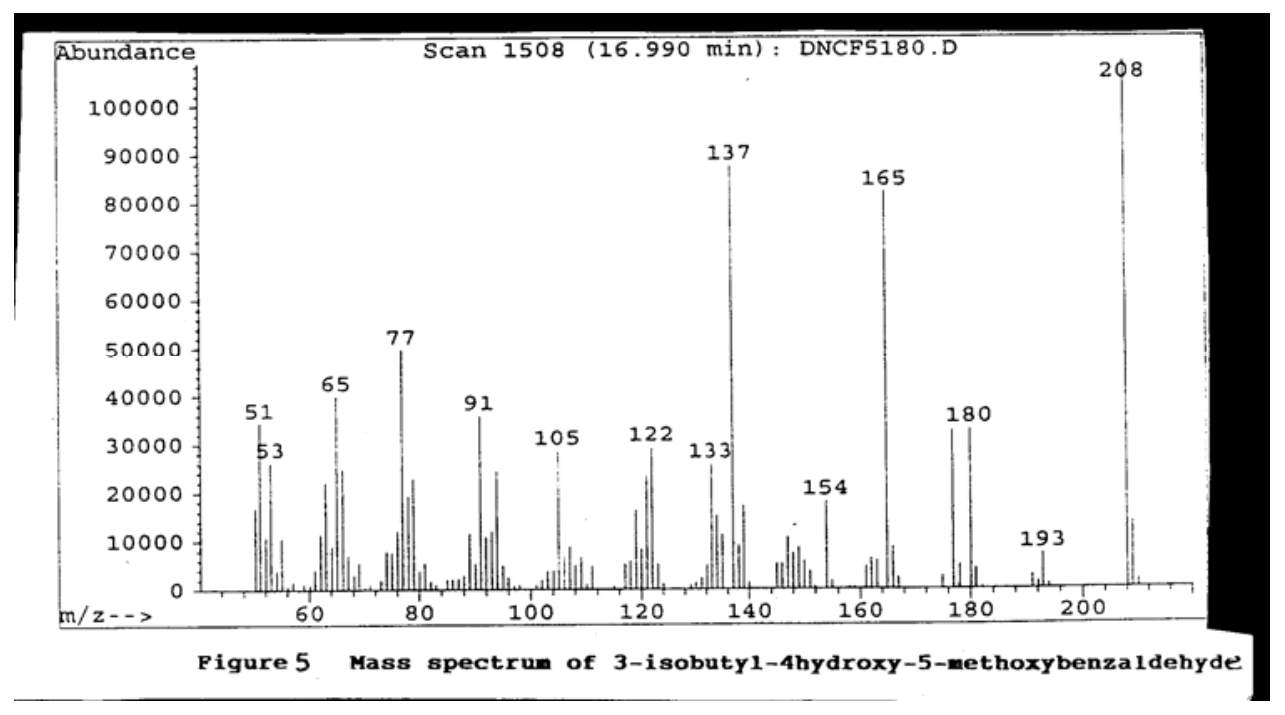

\section{CONCLUSION}

The diversity of activity of alumina-supported $\mathrm{Pd}$ and $\mathrm{Ni} / \mathrm{Pt}$ catalysts has been demonstrated in the decomposition of elephant grass lignocellulose. While Ni/Pt-alumina strongly favours gaseous product formation, $\mathrm{Pd} / \gamma_{-}$and $\mathrm{Pd} / \lambda_{-}$alumina strongly favour the formation of volatile and non-volatile liquid products.

\section{ACKNOWLEDGEMENTS}

This work was supported by the University of Jos Senate Research Grant no. RGC/1996/97/00010. We also acknowledge the technical support of the Department of Chemistry, the University of Florida at Gainesville, Florida, USA, for the running of the GC/MS spectra, and that of the Institute of Industrial and Petroleum Chemistry, the Technical University of Aachen, Germany, for providing the catalysts.

\section{REFERENCES}

1. Ekwenchi, M.M., Araka, B.E. and Ekpenyong, K.I., Ind. Eng. Chem. Res. 27(1988) 2169.

2. Ekwenchi, M.M., Akunwanne, B.U., Okeke, N.R. and Ekpenyong, K.I., Fuel 69(1990) 1569.

3. Ekpenyong, K.I., Arawo, J.D., Melaiye, A., Ekwenchi, M.M. and Abdullahi, H.A., Fuel 74 (1995) 1080.

4.Grohmann, K., Wyman, C.E. and Himmel, M.E., in Rowell, R.M., Shultz, T.P. and Narayan, R., eds., Emerging Technologies for Materials and Chemicals, ACS Symposium series 476, 1992.

5. Katzen, R.., ACS Symposium on Biomass as a Non-fossil Fuel Source, ACS, Washington, D.C., 1979.

6. Scott, D.S., Piskorz, J. and Radlein, D., Ind. Eng. Chem. Process Des. Dev. 24(1985) 581.

7. Antal, M.J., in Klass, D.L., ed.., Energy from Biomass and Wastes, Wiley, Chicago, 1978.

8. Appel, H.R., Fu, Y.C., Friedman, S., Yovorosky, P.M. and Nender, L., Converting Organic Wastes to Oils, in US 
Bureau of Mines, Report of Investigation no. $7560,1971$.

9. Diebold, J.P., ACS Symposium on alternative feedstock for petrochemicals, ACS, Div. of Petrochemistry, Las Vegas, 1980.

10. Waterman, W.W., ACS Symposium, Orlando, FL, 1976.

11. Kuester, I.L., ACS Symposium on biomass as a non-fossil fuel source, Honolulu, Hawai, 1979.

12. Kaminsky, W., Chem. Ing. Tech. 61:10 (1989) 775.

13. Chen., Y., Chem. Abstr. 113(1990) no. $61522 \mathrm{v}$.

14. Kurado, K., Inoe, Y. and Sakai, K., J. Anal. Appl. Pyrolysis, 18:10(1990) 59.

15. Kunetsov, B.N. and Shchipko, M.L., Bioresource Technol. 52:1(1995)13.

16. Nunn, T.R., Howard, J.B., Longwell, J.P. and Peters, W.A., Ind. Eng. Chem. Process

Des. Dev. 24(1985)844.
17. Crawford, D.L., Appl. Environ. Microbiol. 35(1978)1041.

18. Gates, B.C., Catalytic Chemistry, p. 396, John Wiley and Sons Inc., New York, 1992.

19. Sarkanen, K.V. and Ludwig, C. M., eds., Lignins, Occurrence, Formation, Structure and Reactions, p.916, Wiley Interscience, New York, 1971.

20. Koshijima, T. and Yaku, F., in Glasser, W.G. and Sarkanen, S., eds., Lignin, Properties and Materials, Vol. 397, p. 11, ACS, Washington, D.C., 1989.

21. Silverstein, R.M., Bassler, G.C. and Morril, T.C., Spectrometric Identification of Organic Compounds, p.5, John Wiley and Sons, Inc., New York, 1974.

22. Drummond, A.R. and Drummond, I.W., Ind. Eng. Chem. Res. 35(1996)1263.

Accepted 30/12/2002

Received 6/11/2002 